\title{
The problem of coherent speech of children of junior preschool age in modern scientific discourse
}

\author{
I. A. Hrechyshkina \\ Postgraduate department of Preschool and Elementary Education \\ State Institution "Lugansk Taras Shevchenko National University" \\ Starobelsk Lugansk region \\ Corresponding author. E-mail: grechishkina0807@gmail.com
}

Paper received 16.04.19; Accepted for publication 01.05.19.

https://doi.org/10.31174/SEND-PP2019-198VII80-04

\begin{abstract}
The article reveals particularities of establishment, formation and development of coherent speech of preschool children, which was the subject of researches of scientists from different industries. It is revealed the particularities of propaedeutical work in development of coherent speech for children of junior preschool age. Modern and previous researches of speech development of preschoolers are analyzed. It is analyzed and disclosed that the first place in formation of beginning of coherent speech for children of junior preschool age must be taken by development of those aspects of each language tasks (phonetic, lexical, grammatical) that affect the construction of coherent expression. It is characterized the work of each of these parts. The article compares and discloses the concept of monologue and dialogue.
\end{abstract}

Keywords: coherent speech, cohesion of speech, dialogue, monologues.

Actuality of problem of optimization of the initial stage of speech development of children is predefined by the emergency role of language and speech in life of a separate person and society on the whole. Speech development of a child is a main instrument by means of that he or she makes contact with environment and due to this contact the socialization of a child happens. At the same time, as practice proves, distribution of processes of computerization, availability of television and other technical equipments in family and in preschool establishments even for children of preschool age, limits face-to-face communication of children with other speakers, as a result their cognitive sphere is enriched and speech sphere is slowed at the same time. Besides speech competence is one of leading base characteristics of a personality that is formed on the stage of preschool childhood (A. Bohush, N. Havrysh, A. Zrozhevska, K. Krutii, T. Pirozhenko, O. Ushakova and others). However not always the methodology of speech work with preschool children takes into account modern tendencies. Especially this process needs optimization in work with junior preschool children, that makes the problem of speech development of children of preschool age urgent [1].

The essence of the investigated problem consists in that in the theory and practice of preschool education basic directions of methodology of language development are worked out full enough, however, as results of the researches conducted during the last decade in the range of problems of speech development of children and the practice of work of preschool establishments prove the advantage of individual differences above age-old norms, that is a complicative factor in organization of speech work. Study of particularities of speech development of children of early and junior age, unfortunately, during last decades not only in Ukraine but also abroad, became the subject of research only of insignificant number of scientific researches (L. Kalmykova, H. Lopatina, T. Naumenko, O. Saprykina, S. Tseitlin, T. Yurtaikina and others). Marking the specific of speech development of kids, scientists mark the necessity of optimization of this process not only due to speech lessons, but also in other types of activity. The study of experience of organi- zation of speech work in preschool establishments proved convincingly, that many preschool children felt difficulties in creation of coherent expression (text), because the work in development of coherent speech is conducted not always timely and often without taking into account individual and language development of each child.

The aim of this article is baring of particularities of propaedeutic work in coherent speech development of children of junior preschool age.

The problem of coherent speech occupies a central place in researches of language ontogenesis. It is conditioned by its social meaningfulness and role as a higher form of intellectual and speech activity in development of personality of a child.

The particularities of establishing, forming and development of coherent speech of children of preschool age were the subject of researchs of scientists of different industries: psychology (L. Vyhotskyi, O.Luriia, H. Leushyna, J.Piaget, S. Rubinstein, D. Yelokin and others), psycholinguistics (L. Kalmykova, M. Rozhdestvenskyi, T. Ushakova, L. Shcherba, N. Kharchenko and others), teachers (V. Zakharchenko, E. Korotkova, N. Kusina, Ye. Tykheieva, D. Fesenko and others), linguodidactics (A. Bohush, N. Havrysh, K. Krutii, L. Palamar and others).

Native language acquirement envisages formedness of basic knowledge about language as a sign system of people and means of communication. During preschool childhood a child must learn not only to set a contact, conduct conversation, trying to understand and report his or her necessities and ideas to others. A preschool child must also learn to build coherent expressions: to name objects (it is an apple), describe them, tell about an event, phenomenon, sequence of actions; to express own attitude, think (O. Akhmatova, M. Zhynkin, I. Synytsia and others). Such story consists of row of sentences, that characterize substantial parts and properties of that phenomenon that is described; must be logically related to each other and opened out in a certain sequence, in order a listener could fully and exactly understand a speaker. In this case we will deal with coherent speech, id est with semantic, logical, sequential, clear enough speech that 
does not need additional questions and clarifications (A. Arushanova, A. Bohush, O. Ushakova).

The concept "coherent speech" is identified in the dictionary of linguistic terms as a difficult and multidimensional phenomenon that is used in different values: as a process and as a product of language activity, and it is determined as a "segment of speech that owns a considerable extent and is dismembered on more or less complete independent parts" [2].

Coherent speech, as S. Rubinstein marks "it is such a speech that can be clearly enough due to its own subject content; everything in it becomes clear for others from the context of speech" [3].

In I. Synytsia's opinion, cohesion of speech is first of all logic of its ideas, their sequence, interdependence, evidentialness. It to some extent depends on the connectedness of thinking [4]. A child learns to think, learning to talk, he or she also improves own speech while learning to think.

H. Borodyn determines coherent speech as a verbal expanded expression (row of logically united sentences) that provides communication and mutual understanding of people [5]. So for the achievement of cohesion of speech, it is necessary to be able not only to select maintenance that needs to be passed but also to use necessary for this purpose language means.

On the basis of theoretical analysis, we defined own understanding of coherent speech as a certain product not only speech, but also intellectual activity, that is clear for another person and provides communication and mutual understanding of people. In order to tell about something fine and coherently, it is necessary clearly to imagine the object of the story (subject, event), to be able to analyse, to select basic (for the certain situation of communication) properties and features, set cause-and-effect, time and other relations between subjects and phenomena.

In scientific works, devoted to the period of babyhood, it is specified on that development of language of children of the third year of life is necessary to examine as a preparatory stage in acquirement of ability to build coherent expression (N. Aksarina, H. Liamina, M. Koltsova, T. Naumova, M. Popova and others).

On the first plan in beginning of forming of coherent speech for children of junior preschool age development of those parts of each language tasks (phonetic, lexical, grammatical) that influence on the construction of coherent expression must come forward. Our aim is to consider each of these language tasks. The results of special researches of child's speech (O. Hvozdiev, D. Yelokin, H. Liamina, S. Tseitlin, N. Shvachkin and others) proved that phonematic rumor is developing very early. Already in the age of two years children distinguish all subtleties of native speech, understand and react on words that differ in only one phoneme. Such level of development of phonematic rumor is sufficient for a valuable communication, but most scientists that studied the particularities of speech development of children with phonematic excalation of speech (N. Zhukova, H. Kashe, O. Mastiukova, A. Nikashyna, L. Spirova, V. Tarasun, A. Yastrebova and others) repeatedly specified on their difficulties in the acquirement of verbal coherent speech skills. Scientists marked that skills of voice analysis do not arise up for children spontaneously on its own, because such require- ment in their practice of speech communication never arose up. The task to acquire these actions is put to the adults, and actions in particular are formed in the process of the specially organized study during that children master the algorithm of voice analysis (L. Zhurova, D. Elkonin).

Traditionally the central task of lexical development in preschool age was determined extension of vocabulary in the process of acquaintance with environment, id est its quantitative accumulation in passive, and first of all in active vocabulary [6]. The task of lexical development is determined as caring not only of quantitative accumulation of vocabulary of a child but also of mastering by the child properties of new words, understanding of connection between a word and a context, between words, incorporated in thematic groups (A. Honcharenko, N. Horbunova, K. Krutii, Ye. Strunina, N. Kharchenko). Development for a child sense of language, education of regardful, careful attitude toward a word as express of spirituality of a person, his or her aesthetic tastes and ethic convictions needs attention.

The task of grammatical side is mastering of morphology by preschool children that studies structure and grammatical meaning of a word (declination by genders, numbers, cases) ; word building (aspects of wordformation, functioning and structure of derivatives and compound words); syntax (connections and word-order, general properties of sentence). That is why mastering grammatical rules in a practical way, a child begins to understand semantic relations, studies correctly to build phrases and unite them in a sentence (L. Kalmykova, K. Krutii, H. Nikolaichuk). The aim of such a work scientists see in mastering of language generalizations by children, that must take place not through emulating the language standards of educator, but first of all due to own productive actions, hands-on speech practice [6].

Thus, quality of coherent speech depends on the level of development of all parts of speech (phonetic, lexical, grammatical), all achievements of preschool child appear in acquirement of native speech.

Coherent speech executes the row of important functions main of that is communicative one that is realized in two basic forms - dialogue and monologue. Each of these forms has the specific features that predetermines maintenance and character of methodology of their forming. Linguistics contrasts dialogic and monologue speech, coming from their different communicative orientation, linguistic and psychological nature [7].

Coherence of monologue speech begins to form in the heart of dialogue as a leading form of speech communication. Characteristics of dialogic and monologue speech are given in many works (A. Bohush, A. Borodych, N. Havrysh, I. Lutsenko, M. Pentyliuk, V. Skazkina, O. Ushakova, L. Fedorenko, H. Fomichova, L. Shcherba and others).

On determination of S. Yermolenko, a dialogue is a form of language communication, the participants of that interchange remarks-expressions. Essentially, a dialogue is the interchange of listening and pronouncing mostly of small, incomplete, elliptic sentences of simple structure, which are used by interlocutors.

Scientists underline that a dialogue, as a rule, takes place in a certain situation and is accompanied by active 
and expressive intonation, facial gesture, gestures (H. Lopatina, T. Pirozhenko). Interlocutors know common subject of conversation, that is why ideas and judgements are compressed, incomplete, sometimes fragmentary. Preferential using of colloquial vocabulary and phraseology, understatement, briefness, presence of simple and difficult conjunctionless sentences, improvisation, reactive character of expressions belong to linguistic characteristics of dialogue. Typical for dialogic speech is active application of patterns, cliches, speech stereotypes, permanent formulas of communication (L. Yakubynskyi). Coherence as a characteristic of any text is also peculiar to dialogue, only, as a well-known psycholinguist O. Leontiev marked, coherence in a dialogue is set by several interlocutors [6].

Monologue is a speech of one person, oriented to perception of it by other people, that does not envisage immediate, direct response of listeners. An orientation on a listener requires clearness and richness of content of speech, indeed information that a speaker wants to express is unknown for others.

Scientists refer application of mainly literary vocabulary; uncoiling of expression; presence of complicated syntax structures; aspiring to clear grammatical arrangement of coherence on the basis of development of the system of elements of coherence; certain completeness to linguistic characteristics of monologue. A speaker uses mostly extralinguistic and intonation facilities of expressiveness, however, unlike a dialogue, they play a secondrate role, as a monologue is less emotional [7].

A little bit doubtful is confirmation of D. Barannik in relation to monologue speech as one-sided manner of speaking, uncounted on an immediate corresponding verbal reaction, as, in our opinion, is complete not enough [8].

The determination of this term, given by O. Leshenko, specifies on such characteristic, as that, how many people participate in speech it is a speech of one person, while all other people listen only, and they do not participate in it directly, id est speech is sent to a listener, but a listener is passive, he or she does not take active part in development of maintenance of speech [9].

Thus, the problem of coherent speech of children of preschool age on the modern stage is exposed in many aspects and continues to exose that is proved by works, researches of many modern scientists. At the same time possibilities of junior preschool children in development of coherent speech remain not enough studied. The insufficient theoretical worked out of problem presents difficulties in work of educators with children of junior preschool age.

\section{REFERENCES}

1. Bohush, A. M. (1997). Zaproshuiemo do rozmovy: posibnyk dlia roboty $\mathrm{z}$ doshkilniatamy [Inviting for talk: manual for work with pre-schoolers]. Kyiv: Osvita [in Ukrainian].

2. Akhmatova, O.S. (1986). Slovar lingvisticheskih terminov [Dictionary of linguistic term]. Moscow: Pedagogy [in Russian]

3. Osnovy obshchei psihologii [Bases of general psychology] (1989). Moscow: Pedagogy, p.468-469 [in Russian]

4. Psykholohiia usnoho movlennia [Psychology of oral speech] (1974). Kyiv: Rad.pik. p.150 [in Ukrainian].

5. Metodika razvitiya rechi detey [Methods of speech development of children] (1984). - M.: Prosveshcheniye, 1984. - S. 44 (1984). M .: Education, 1984. - p. 44 [in Russian]

6. Havrysh, N.V. (2006). Rozvytok zviaznoho movlennia doshkilniat [Developmet of coherent speech of preschoolers]. Kyiv: shkilnyi svit [in Ukrainian]

7. Bohush, A. M. (2007). Doshkilna linhvodydaktyka: teoriia i metodyka navchannia ditei ridnoi movy [Preschool linguodidactics: theory and methods of native language teaching for children]. Kyiv: vyshcha shkova [in Ukrainian].

8. Barannik, D.Kh. (1969). Usnyi monoloh: zahalni osoblyvosti movnoi kultury [Oral monologue; general particularities of language culture]. Dnipropetrovsk: VDU [in Ukrainian].

9. Leshchenko, O.M. (1972). Metodyka navchannia ridnoi movy i hramoty [Methods of native language and grammar teaching]. Kyiv: vyshcha shkola [in Ukrainian]. 